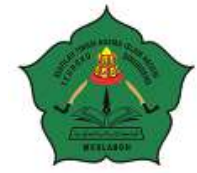

AT-TASYRI' Jurnal Ilmiah Prodi Muamalah

P-ISSN: 2085-2541, E-ISSN: 2715-7865

Volume 13, Nomor 2, Desember 2021

https://ejournal.staindirundeng.ac.id/index.php/Tasyri

\title{
HARTA BERSAMA AKIBAT PERCERAIAN DALAM PERSPEKTIF UU NO 1 TAHUN 1974 TENTANG PERKAWINAN DAN KOMPILASI HUKUM ISLAM
}

\author{
Bukhari* \\ Fakultas Syariah IAIN Lhokseumawe \\ *bukhari@iainlhokseumawe.ac.id \\ Anwar \\ STAIN Teungku Dirundeng Meulaboh \\ anwarpante@gmail.com
}

\begin{abstract}
Abstrak
Perkawinan dan perceraian serta harta bersama merupakan serangkaian yang tidak dapat dipisahkan dari rumah tangga. Itu adalah bagian normal dari berkeluarga. dengan zaman yang semakin maju dan di globalisasi tidak selamanya perkawinan dalam keluarga dan masyarakat berjalan dengan normal. Ditengah-tengah masyarakat banyak timbul masalah-masalah dalam perkawinan yang memerlukan penyelesaian,salah satu diantaranya adalah masalah harta bersama dalam perkawinan. Permasalahan timbul atau berkembang menjadi suatu kasus setelah adanya perceraian atau kematian salah satu pihak atau kedua-duanya. Kalau persoalan harta bersama bisa diselesaikan secara musyawarah atau kekeluargaan akan menjadi hal yang baik, tetapi bila timbul ketidaksesuaian pendapat maka persoalan harta bersama ini bisa menjadi besar bahkan sampai ke Mahkamah Syari'yah untuk penyelesaiannya. Oleh karena ruang lingkup penelitian ini adalah pada disiplin hokum positif, maka dalam penelitian ini penulis menggunakan penelitian hukum normatif yang merupakan salah satu jenis penelitian yang dikenal umum dalam kajian ilmu hukum.Penelitian ini merupakan bagian dari penelitian kepustakaan yakni dengan cara meneliti bahan pustaka atau yang dinamakan penelitian hukum normatif. Hasil penelitian ini menunjukkan bahwa perkawinan, perceraian dan harta bersama merupakan suatu hal yang sangat prinsipil, karena berkaitan erat dengan akibat-akibat perkawinan.
\end{abstract}

Kata Kunci: Harta Bersama, Perceraian KHI, Undang-Undang.

\begin{abstract}
Marriage and divorce and joint property are a series that cannot be separated from the household. It's a normal part of having a family. With an increasingly advanced era and globalization, marriage in the family and society does not always run normally. In the midst of society many problems arise in marriage that require resolution, one of which is the problem of joint property in marriage. Problems arise or develop into a case after the divorce or death of one or both parties. If the issue of joint property can be resolved by deliberation or kinship, it will be a good thing, but if there is a discrepancy of opinion, then the issue of joint property can become large and even reach the Syari'yah Court for resolution. Because the scope of this research is on positive legal disciplines, in this study the author uses normative legal research which is one type of research that is commonly known in the study of legal science. This is called normative legal research. The results of this study indicate that marriage, divorce and joint property are very principal matters, because they are closely related to the consequences of marriage.
\end{abstract}

Keywords: Joint Assets, KHI Divorce, the Law. 


\section{A. PENDAHULUAN}

Dalam kehidupan membina rumah tangga harapan semua orang tentunya hidup bahagia namun tetap saja itu hanya sebuah keinginan. Harta bersama sebagaimana dijelaskan oleh undang-undang Perkawinan No 1/1974 didefinisikan sebagai harta yang didapatkan atau dihasilkan dalam masa pernikahan antara kedua belah pihak. ${ }^{1}$ Sedangkan harta yang mereka bawa masingmasing, tetap dipandang sebagai harta bawaan selama tidak ada perjanjian perkawinan yang menentukan lain. Persoalan harta ini menjadi penting untuk dibicarakan karena sederhananya adalah karena harta merupakan kebutuhan manusia dalam menjalankan kehidupan di muka bumi ini. Jadi harta sesungguhnya sesuatu yang tidak dapat diabaikan dalam sebuah kehidupan keluarga.

Islam sangat menganjurkan umatnya untuk segera menikah atau berumah tangga, dan itu semua harus dibarengi dengan kemampuan finansial untuk dapat menafkahi keluarga. Seringkali yang memicu pertengkaran di dalam keluarga adalah disebabkan ketidakmampuan suami memenuhi kebutuhan material keluarganya. Kendati demikian sebaliknya, ketercukupan harta juga dapat menimbulkan masalah di dalam keluarga. Terlebih lagi ketika masingmasing pihak memiliki kemampuan untuk produktif menghasilkan harta.

Perkawinan pada dasarnya merupakan ikatan yang sangat kuat antara seorang laki- laki dan wanita, yang tidak saja mengandung dimensi lahiriah tetapi juga mengandung dimensi batiniah. Tidak saja memiliki sisi material tetapi juga sisi spiritual. Dengan demikian, perkawinan dalam Islam kendati disebut dengan kontrak tidak berarti perkawinan merupakan peristiwa perdata semata. ${ }^{2}$ Penting untuk dicatat, keluarga merupakan suatu unit terkecil yang terdiri dari sepasang suami-istri dan anak-anak. Selanjutnya keluarga akan membentuk komunitas yang lebih luas yang disebut dengan masyarakat. Pada gilirannya, himpunan masyarakat ini menjelma menjadi sebuah tatanan masyarakat yang lebih kompleks yang disebut dengan negara. kokohnya sebuah bangsa dan masyarakat akan sangat ditentukan oleh kondisi keluarga itu sendiri.

Di dalam penjelasan tentang keluarga sakinah di atas, jelas dinyatakan bahwa salah satu ukuran sakinah itu adalah kecukupan harta benda. Tidak dapat dipungkiri, harta kekayaan di dalam kehidupan keluarga merupakan faktor yang sangat menentukan dalam pembentukan keluarga sakinah. Lebih jauh dari itu harta tidak saja sebagai kebutuhan hidup yang berfungsi untuk memenuhi fungsi-fungsi primer, tetapi juga harta berfungsi untuk memenuhi kebutuhankebutuhan yang bersifat sekunder dan tertier. Akan tetapi sekali lagi penting diingat, tidak semua keluarga yang secara ekonomi dapat dikatakan mapan akan menjamin mereka

${ }^{1}$ Di dalam UU No 1/1974 Pasal 35 ayat 1 dinyatakan, Harta benda yang diperoleh selama perkawinan menjadi harta bersama. Pada ayat 2 dinyatakan, Harta bawaan dari masing-masing suami dan istri dan harta benda yang diperoleh masing-masing sebagai hadiah atau warisan, adalah dibawah penguasaan masing-masing sepanjang para pihak tidak menentukan lain.

${ }^{2}$ Salah satu kritik yang diajukan para pakar terhadap konsep CDL (Counter Legal Draft) Kompilasi Hukum Islam yang dimotori oleh Musdah Mulia adalah karena materi CDL menempatkan perkawinan hanya sekedar akad perdata. Tegasnya hanya sekedar kontrak. Lihat, Muhammad Zain dan Mukhtar Alshodiq, Membangun Keluarga Humanis: Counter Legal Draft Kompilasi Hukum Islam yang Kontroversial itu, (Jakarta: Graha Cipta, 2005) h. 23-24. Bandingkan dengan Huzaimah Tahido Yanggo, dkk. Membendung Liberalisme, (Jakarta: Republika, 2006) h. $78-130$. 
dapat hidup dengan harmonis. Faktanya banyak juga keluarga yang dilihat dari sisi material dapat dikatakan berkecukupan namun mereka tidak harmonis.

Tentu saja banyak factor yang menyebabkan kehidupan keluarga yang mengalami disharmonisasi ini, seperti konflik dan ketegangan, kekerasan dalam rumah tangga, dan perselingkuhan. Jika faktorfaktor yang menyebabkan disharmonisasi keluarga ini tidak dapat diatasi, maka yang timbul adalah perceraian. Secara hukum, perceraian tidak saja menimbulkan bubarnya pasangan suami-istri tetapi juga membawa kepada konsekuensi hukum yang lain, seperti hak asuh anak atau hak hadhanah, tanggung jawab suami selama masa iddah, dan tidak kalah pentingnya adalah tentang pembagian harta bersama. Harta bersama telah diatur dalam Undang-undang nomor 1 tahun 1974 dalam bab 8 yang berjudul "putusnya perkawinan serta akibatnya" yang termuat dalam pasal 38 sampai dengan pasal 41 dan juga pada Peraturan Pemerintah Republik Indonesia Nomor. 9 tahun 1975 dalam bab 5 (tata cara perceraian) termuat dalam pasal 14$36 .^{3}$

Apabila perceraian terjadi di antara kedua belah pihak sebelum mempunyai anak dan harta pun belum didapat selama pernikahan maka permasalahan tidak akan begitu sulit. Namun sebaliknya, jika anak dan harta sudah dimiliki ketika terjadinya perceraian maka persoalannya akan panjang. Sebab seluruh yang terkait dalam pernikahan itu baik harta bersama, anak, dan lain sebagainya akan menjadi bahagian yang tidak terlepas dari perceraian itu.

Di dalam UU Perkawinan No 1/1974 pada pasal 35-37 dijelaskan tentang hal-hal yang berkenaan dengan harta bersama. ${ }^{4}$ Tegas dinyatakan bahwa harta bersama adalah harta yang diperoleh selama perkawinan. Agaknya yang menarik diperhatikan adalah bunyi pasal 37 yang menyatakan bahwa apabila terjadi putusnya perkawinan, maka harta bersama diatur menurut ketentuan hukum masing-masing yaitu hukum adat, Barat maupun Islam. Melalui pasal 37 ini jelas bahwa undangundang perkawinan tidak memberi ketentuan secara pasti mengenai pengaturan harta bersama jika terjadi perceraian, melainkan menunjuk kepada hukum masing-masing. Bisa saja maknanya kembali kepada hukum adatnya masing-masing, namun dapat pula bermakna akan kembali kepada hukum agama Islam dalam hal ini fikih. ${ }^{5}$

\footnotetext{
${ }^{3}$ irektur Pembinaan Badan Peradilan Islam, Himpunan Peraturan PerundangUndangan Dalam Lingkungan Peradilan Agama (Jakarta: tp, 2001), h. 139-140.

${ }^{4}$ Adapun bunyi Pasal 35 UU Perkawinan No 1/1974 adalah, 1). Harta benda yang diperoleh selama perkawinan menjadi harta benda bersama. 2). Harta bawaan dari masing-masing suami dan isteri dan harta benda yang diperoleh masing-masing sebagai hadiah atau warisan adalah di bawah penguasaan masing-masing sepanjang para pihak tidak menentukan lain. Selanjutnya pada pasal 36 berbunyi, 1). Mengenai harta bersama, suami isteri dapat bertindak atas persetujuan kedua belah pihak. 2). Mengenai harta bawaan masing-masing, suami dan isteri mempunyai hak sepenuhnya untuk melakukan perbuatan hukum mengenai harta bendanya. Sedangkan pasal 37 berbunyi, Bila perkawinan putus karena perceraian, harta bersama diatur menurut hukumnya masing-masing. Tentang harta bersama lebih rinci lagi diatur dalam Kompilasi Hukum Islam bab XIII dengan judul harta kekayaan dalam perkawinan pada pasal 85-97.

${ }^{5}$ Dalam kajian fikih klasik khusunya dalam bidang muamalat harta bersama cendrung disamakan dengan syirkah atau harta yang diusahakan secara bersama oleh suami isteri. Meskipun pada hakikatnya persamaan tidak terlalu tepat dalam pengkategoriannya. Hal itu disebabkan para ulama klasik belum mengenal dengan apa yang disebut pencarian bersama antara suami dan isteri dalam tradisi masyarakat pada waktu itu. Karena pada umumnya perempuan hanya sebatas di rumah sedangkan untuk masalah pencari penghidupan mutlak hanya bagi suami. Kendatipun demikian, sebab konsep syirkah itu sendiri beragam dalam pelaksaannya maka paling tidak dapatlah masalah harta bersama ini didekatkan dengan konsep syirkah. Dalam konsep syirkah ada yang disebut dengan syirkah al-abdan, yaitu modal dari suami kemudian isteri mempunyai andil dalam hal jasa dan tenaganya.
} 
Kembali ke Undang-undang perkawinan No 1/1974, bahwa di dalam pasal 37 di atas tampaknya tidak ada penjelasan mengenai status perceraian yang mengharuskan pembagian harta bersama tersebut. Jika perceraian tersebut dilakukan secara baikbaik, karena tidak ada kecocokan antara satu dengan yang lain, dan keduanya sepakat untuk mengakhiri perkawinan, maka pembagian harta bersama menjadi pantas. Namun bagaimana pula jika perceraian itu terjadi karena salah satu pihak berselingkuh atau melakukan pengkhianatan di dalam perkawinan. Apakah salah satu pasangan yang berselingkuh ini masih pantas mendapatkan harta bersama. Disebabkan masalah-masalah ini tidak begitu jelas peraturannya, maka seringkali keputusannya diserahkan kepada lembaga Peradilan. Dalam beberapa kasus, persoalan harta bersama ini erat kaitannya dengan masalah perceraian, maka keputusannya seringkali bersamaan dengan perceraian.

\section{B. LANDASAN TEORITIS}

\section{Harta bersama menurut UU}

Secara yuridis formal, aturan-aturan tentang harta bersama sudah ditentukan dalam pasal 35 ayat 1 UU No 1 tahun 1974 tentang perkawinan, sebagaimana telah diuraikan sebelumnya. Pertanyaan yang menarik untuk diajukan adalah, mengapa UU Perkawinan memuat aturan harta bersama yang selanjutnya juga diikuti oleh KHI. Pertanyaan ini hemat saya perlu dijawab karena fikih Islam sebenarnya sama sekali tidak mengenal apa yang disebut dengan harta bersama. Ada
3 jawaban mengenai harta bersama menurut undang-undang perkawinan dan kompilasi hokum Islam :.6

a. UU Perkawinan melihat bahwa perkawinan pada dasarnya menganut asas keseimbangan dan kesetaraan. Baik suami atau istri yang di dalam UU sering disebut sebagai kepala keluarga dan ibu rumah tangga. Keduanya memiliki kedudukan yang sama dengan fungsi-fungsi yang berbeda. Jadi tidaklah boleh yang satu menganggap dirinya lebih superior dibanding dengan yang lain. Konsekuensinya mereka berdua harus membangun kerjasama yang baik dalam suasana saling menghargai dan menghormati. Konsekuensinya karena apa yang mereka lakukan sesuai dengan fungsi masingmasing adalah satu bentuk kerjasama, di mana keberhasilan yang satu sangat ditentukan oleh keberhasilan yang lain pula, maka apapun yang dihasilkan selama perkawinan itu berlangsung adalah milik bersama. Dengan kata lain, kita dapat menyebutnya sebagai harta bersama.

b. Rumusan harta bersama sebenarnya adalah perwujudan dari konsep maslahat sebagai tujuan syari'at. ${ }^{7}$ Selama ini perempuan selalu saja berada pada posisi yang tersubordinasi. Hal ini semakin tampak pada perempuan atau istri-istri yang tidak bekerja di luar rumah. Posisi istri yang hanya bekerja di rumah, mengurusi

Kemudian yang lain, apa yang disebut dengan syirkah 'inan, yaitu dimana kedua belah pihak suami dan isteri masingmasing mendatangkan modal untuk dikelola secara bersama. Realitas di tengah-tegah masyarakat kita kebanyakan yang terjadi adalah model syirkah abdan, artinya lebih banyak suami yang mencari nafkah untuk menghidupi keluarga sedangkan isteri hanya mengatur sirkulasi perbelanjaan rumah tangga. Tentunya ketika terjadi perselisihan dan berujung pada perceraian maka kaitannya dengan penyelesaaian harta bersama merupakan menjadi persoalan yang cukup pelik.

${ }^{6}$ Lihat Abdul Aziz Dahlan, Ensiklopedi, h. 389

${ }^{7}$ Abdul Wahab Khallaf, Ilmu Ushul al-Fiqh (Jakarta: Maktabah al-Sa'wah alIslamiyah, 1990), h. 84. 
anak-anak, sebenarnya sangat lemah bila berhadapan dengan suami. Posisi yang lemah ini seringkali dianggap karena istri tidak produktif dalam menghasilkan harta. Pada hal apa yang dilakukannya dengan bekerja di dalam rumah, mengurus rumah, mendidik anak-anak dan mempersiapkan seluruh kebutuhan anak-anaknya adalah sebuah pekerjaan besar dan tidak dapat dilihat sebagai kewajiban semata-mata. Oleh sebab itu, si istri yang berada di rumah harus dipandang sebagai kerja yang layak mendapatkan reward yang pantas. Keputusan hukum untuk menyebut apa yang dihasilkan suami lewat kerjanya di luar rumah, disebut sebagai harta bersama di mana si istri juga memiliki hak yang sama adalah sebuah keputusan hukum yang sangat adil dan menjamin kemaslahatan. Dengan demikian dapatlah dikatakan bahwa praktek seperti ini pada dasarnya tidak bertentangan dengan nilai-nilai dan tujuan syari'at seperti keadilan dan kemaslahatan. Lebih dari itu harta bersama ini memiliki pijakan cultural budaya yang kuat di dalam masyarakat.

c. Seringkali ketika terjadi perceraian, wanita menjadi korban yang terkadang penderitaannya berlipat ganda. Ia seolah tidak dibutuhkan oleh suaminya lagi dan ada kesan merasa tidak berguna. Inilah tekanan psikologis yang paling berat dihadapi oleh para istri yang telah diceraikan. Penderitaan selanjutnya adalah mereka menjadi tidak berdaya karena tidak mendapatkan apapun dari perkawinan yang telah berlangsung. Pada hal selama ini dia turut serta membantu suaminya untuk memperoleh harta. Singkatnya, istri yang telah diceraikan tidak mendapatkan jaminan kehidupan bahkan cenderung untuk menjadi beban bagi keluarga asalnya. Oleh sebab itu diaturnya harta bersama di dalam perkawinan, pada hakikatnya adalah untuk memberikan jaminan kepada perempuan atau istri-istri akan hakhaknya. Setidaknya dengan adanya harta bersama, setiap istri yang telah ditalak oleh suaminya dapat melanjutkan kehidupannya.

Dari gambaran di atas, jelas pertimbangan kemaslahatan terutama bagi istri yang diceraikan atau ditinggal mati oleh suaminya sangat jelas tergambar di dalam UU Perkawinan dan KHI. Tidak dapat dipungkiri bahwa kemaslahatan adalah menjadi tujuan dari syari'at Islam (maqasid al-syari'ah). Sehingga sering disebut, dimana ada kemaslahatan maka di sanalah terdapat hukum Allah.

Oleh sebab itu, upaya para ahli fikih untuk mendekatkan harta bersama lewat syirkah, hemat saya layak dipertimbangkan. Namun hal yang perlu diperhatikan adalah konsekuensinya. Jika dasar pertimbangannya adalah konsep syirkah, maka berlakulah sekurang-kurangnya syarat normative (bukan syarat prosedural seperti adanya orang yang berakad, sighat dan seterusnya) seperti saling amanah. Artinya jika salah seorang dari unsur yang bersyarikat itu berlaku khianat, maka gugurlah haknya terhadap hasil syarikat atau paling tidak kedudukannya tidak lagi sama dengan teman syarikatnya yang masih jujur.

\section{Harta bersama dalam KHI}

Dalam pasal 36 Undang-undang No. 1 tahun 1974 di atas sekalipun memberikan syarat penggunaan harta bersama yaitu dengan adanya keizinan dari kedua belah pihak akan kemana digunakan harta tersebut. Jadi, apabila kita bandingkan apa yang terdapat dalam KHI sudah lebih tegas lebih ketat. Ketatnya KHI dalam mengurus harta 
bersama terbukti dengan tidak hanya masalah izin atau tidaknya salah satu kedua belah pihak dalam penggunaan harta tersebut. Namun sebagaimana disebutkan di atas sampai pada batasan penggunaan kepentingan pribadi yang menimbulkan hutang tidak boleh sama sekali menggunakan harta bersama.

Walaupun KHI tersebut dalam tata aturan hukum di negara Indonesia sebatas Instruksi Presiden nomor I tahun 1991 tanggal 10 Juni 1991, kemudian ditindaklanjuti sacara organik melalui keputusan menteri agama No. 154 tahun 1991 tanggal 22 Juli 1991. Namun muatan materinya sudah lebih luas dan tegasnya dari apa yang terdapat dalam Undang-undang No. 1 tahun 1974 tepatnya pasal 35.

Begitu pentingnya kontribusi KHI dalam pengembangan hukum Islam di Indonesia yang termasuk di dalamnya harta bersama, maka apabila kita lihat Inpres nomor I tahun 1991 tanggal 10 Juni 1991, kemudian diantisifasi secara organik oleh keputusan menteri agama No. 154 tahun 1991 tanggal 22 Juli 1991 sekurang-kurangnya terdapat tiga catatan penting yang perlu kita perhatikan: ${ }^{8}$

Pertama, perintah menyebarluaskan KHI tidak lain daripada kewajiban masyarakat Islam dalam rangka fungsionalisasi eksplanasi ajaran Islam sepanjang yang normatif sebagai hukum yang hidup.

Kedua, rumusan hukum dalam KHI berupaya mengakhiri persepsi ganda dari keberlakuan hukum Islam yang ditunjuk oleh pasal 2 ayat (1) serta (2) UU. No 1 Tahun 1974, segi hukum formal di dalam UU. No 7 Tahun 1989 jo UU No. 3 Tahun 2006 sebagai hukum yang diberlakukan secara sempurna.

Ketiga, menunjukkan secara tegas wilayah berlaku pada instansi pemerintah dan masyarakat yang memerlukan. ${ }^{9}$ Inti dari catatan penting di atas, adalah bahwa KHI telah memberikan

sebuah solusi terhadapberagamnya pendapat-pendapat dalam kitab fikih yang kemudian dijadikan panduan umum dalam pengadilan dalam persoalan pernikahan, wakaf, waris, harta bersama. Dengan demikian KHI seharusnya dapat dipahami seluruh umat Islam Indonesia dalam rangka membangun hukum yang jelas dan tidak meragukan lagi. Dengan kata lain dapat dikatakan bahwa KHI dalam persoalan harta bersama sudah secara jelas memberikan gambaran mengenai kondisi sekaligus tata cara serta teknis pelaksanaannya di tengah-tengah masyarakat.

Yang perlu diperhatikan, masuknya lembaga harta bersama di dalam pasal-pasal Kompilasi Hukum Islam bukanlah berdasarkan pendapat-pendapat ulama fikih klasik. Sebabnya, di dalam kitab-kitab fikih klasik hampir tidak ditemukan aturan mengenai harta bersama. Oleh sebab itu, ketika KHI memuat aturan harta bersama, paling tidak ada beberapa alasan yang dapat dikemukakan. Pertama, harta bersama di dalam KHI adalah satu bentuk kompromi penyusunan KHI terhadap adatistiadat yang telah berlaku pada masyarakat Indonesia. Sebagaimana diketahui, hampir seluruh hukum adat di Indonesia mengakui harta bersama. Pada masyarakat Aceh misalnya, dikenal istilah hareuta sihareukat. Dalam masyarakat Melayu dikenal istilah yang sudah popular dengan sebutan harta syarikat, sedangkan pada masyarakat Jawa dikenal istilah gonogini, dan tentu saja banyak istilah lainnya. ${ }^{10}$

Kedua, jika menggunakan kerangka siyasat al-syar'iyyat, aturan KHI tentang harta bersama tidak lebih hanya sebuah operasionalisasi terhadap UU No 1 tahun 1974. Karena secara hirarki perundangundangan di Indonesia, UU nomor 1 Tahun

${ }^{8}$ Abdul Gani Abdullah, Pengantar Kompilasi Hukum Islam Dalam Tata Hukum Indonesia (Jakarta: Gema Insani Press, 1994), h. 62.

${ }^{9}$ Ibid.

${ }^{10}$ Lebih lanjut lihat kembali, Ismuha, Pencaharian Bersama Suami-IStri di Indonesia, (Jakarta: Bulan Bintang, 1978) hal. 41-43 
1974 lebih tinggi kedudukan yuridis formalnya dari KHI yang hanya didasarkan pada INPRES. ${ }^{11}$

Alasan lain agaknya, di dalam pelembagaan harta bersama diyakini mengandung kemaslahatan terutama buat istri. Dalam kenyataan seringkali ketika terjadi perceraian yang disebabkan karena kematian, nasib perempuan sering tidak jelas. Paling tidak, dengan keberadaan lembaga harta bersama, istri memiliki jaminan atau pegangan untuk melanjutkan kehidupannya walaupun mungkin sebatas untuk jangka waktu tertentu.

\section{DATA DAN METODOLOGI}

Penelitian ini menggunakan metode penelitian kualitatif, dengan pendekatan yuridis normatif, dengan mengacu pada sumber-sumber sekunder seperti buku, jurnal, monograf, peraturan perundangundangan, tulisan yang tidak dipublikasi hingga sumber online yang dapat dipercaya kredibilitasnya, setelah mengumpulkan data, selanjutnya ditranskrip dan dipilah dengan membentuk narasi yang dapat dipahami, kemudian disintesis untuk diambil kesimpulan-kesimpulan sesuai kebutuhan dalam penelitian ini, adapun hasilnya disajikan ke hadapan publik luas dalam bentuk narasi yang diawali dari pendahuluan dan ditutup dengan kesimpulan-kesimpulan.

\section{HASIL DAN PEMBAHASAN}

Perkawinan yang diatur dalam UU No. 1 Tahun 1974 tentang Perkawinan. Putusnya perkawinan karena perceraian ada dua sebutan yaitu "cerai gugat" dan "cerai talak", penyebutan ini menunjukkan kesan adanya perselisihan antara suami dan isteri. Dalam hal ini hak untuk memecah perkawinan melalui perceraian tidak lagi monopoli suami.
Isteri diberi hak untuk mengajukan gugatan cerai. Perceraian dengan talak biasa disebut cerai talak hanya berlaku bagi mereka yang melangsungkan perkawinan menurut agama Islam. Sedangkan perceraian dengan gugatan biasa disebut dengan cerai gugat berlaku bagi mereka yang melangsungkan perkawinan menurut agama Islam dan bukan agama Islam. Efek lanjutan yang timbul dari sebuah perceraian selain penetapan tentang status hak asuh anak, nafkah, juga tentang pembagian harta bersama, yang tidak jarang ini juga menimbulkan konflik baru antara suami dan istri pasca perceraian.

Oleh karena itu idealnya suami dan istri harus memahami hak dan kewajiban masingmasing terutama menyangkut harta perkawinan. Secara normatif, apabila kita melihat peraturan yang mengatur tentang harta perkawinan, kita dapat mengkaji dari beberapa pasal dalam KUHPdt dan UndangUndang No. 1 Tahun 1974 tentang Perkawinan. Harta bersama menurut Pasal 119 KUHPdt pada pokoknya dikemukakan bahwa terhitung sejak saat perkawinan dilangsungkan, demi hukum terjadilah persatuan bulat harta kekayaan suami dan isteri sejauh tidak diadakan perjanjian perkawinan tentang hal tersebut. Berdasarkan ketentuan ini dapat diartikan bahwa yang dimaksud harta bersama adalah "Persatuan harta kekayaan seluruhnya secara bulat baik itu meliputi harta yang dibawa secara nyata (aktiva) maupun berupa piutang (pasiva), serta harta kekayaan yang akan diperoleh selama perkawinan".

Menurut Pasal (35) UU No. 1 Tahun 1974 tentang Perkawinan harta benda dalam perkawinan meliputi: a) Harta benda diperoleh selama perkawinan menjadi harta bersama. b) Harta bawaan dari masing-

\footnotetext{
${ }^{11}$ Pagar, "Harta Bersama Suami-Istri (Suatu Tinjauan Terhadap Kompilasu Hukum Islam) dalam Sinar Darussalam No. 205, AGustus 1993, IAIN. Ar-Raniry, Banda Aceh, hal. 58
} 
masing suami dan istri dan harta benda yang diperoleh masing-masing sebagai hadiah atau warisan, adalah dibawah penguasaan masingmasing sepanjang para pihak tidak menentukan lain. Berdasarkan hukum positif yang berlaku di Indonesia, harta bersama dibagi dengan seimbang antara mantan suami dan mantan isteri. Hal ini tentunya apabila tidak ada perjanjian perkawinan mengenai pisah harta dilakukan oleh pasangan suami isteri yang dilakukan sebelum dan sesudah berlangsungnya akad nikah.

Segala urusan yang berkenaan dengan harta bersama harus didasari ketiga sumber hukum positif tersebut. Mengenai harta bersama, dalam Pasal 37 UU No.1 Tahun 1974 mengenai Perkawinan menentukan bahwa bila perkawinan putus karena perceraian, harta bersama diatur menurut hukumnya masing-masing. Yang dimaksud dengan hukumnya masing-masing ialah hukum agama, hukum adat, dan hukumhukum lainnya. Berkaitan dengan harta barsama, hukum positif juga memberikan perlindungan hukum terhadap harta bersama tersebut. Perlindungan ini berupa peletakan sita jaminan terhadap harta bersama jika dikhawatirkan salah satu pihak suami-istri akan melakukan kecurangan, seperti mengalihkan sebagian besar harta bersama kepada pihak ketiga dengan maksud ketika perceraian telah terjadi, harta bersama yang di dapat pihak yang melakukan kecurangan tersebut akan lebih banyak dari yang seharusnya.

Dalam Kompilasi Hukum Islam (KHI) Indonesia, pengertian harta bersama sejalan dengan pengertian harta bersama dalam Undang-Undang Nomor 1 Tahun 1974, Pasal 35 yaitu harta benda yang diperoleh suami istri selama berlangsungnya perkawinan.
Dalam pasal $85 \mathrm{KHI}$ disebutkan adanya harta bersama dalam perkawinan itu tidak menutup kemungkinan adanya harta milik masingmasing suami istri, bahkan dalam pasal 86 ayat (1) disebutkan bahwa pada dasarnya tidak ada percampuran antara harta bersama dan istri karena perkawinan. d. Harta Bersama menurut Kitab UndangUndang Hukum Perdata Di dalam KUH Perdata (BW), tentang Harta Bersama menurut UndangUndang dan Pengurusnya, diatur dalam Bab VI Pasal 119-138, yang terdiri dari tiga bagian. Bagian Pertama tentang Harta Bersama menurut Undang-Undang (Pasal 119- 123), Bagian Kedua tentang Pengurusan Harta Bersama (Pasal 124-125) dan Bagian Ketiga tentang Pembubaran Gabungan Harta Bersama dan Hak Untuk Melepaskan Diri Padanya (Pasal 126-138) ${ }^{12}$.

Menurut KUH Perdata Sejak saat dilangsungkan perkawinan, maka menurut hukum terjadi harta bersama menyeluruh antara pihak suami istri, sejauh tentang hal itu tidak diadakan ketentuan-ketentuan dalam perjanjian perkawinan. Harta bersama itu selama perkawinan berjalan tidak boleh ditiadakan atau dirubah dengan suatu persetujuan antara suami-istri (Pasal 119). Berkenaan dengan soal keuntungan, maka harta bersama itu meliputi barang-barang bergerak dan barang-barang tak bergerak suami istri itu, baik yang sudah ada maupun yang akan ada, juga barang-barang yang mereka peroleh secara cuma-cuma, kecuali bila dalam hal terakhir ini yang mewariskan atau yang menghibahkan menentukan kebalikannya dengan tegas (Pasal 120). Dalam Pasal 122 Kitab Undang-Undang Hukum Perdata atau Burgerlijk Wetboek "Mulai saat perkawinan dilangsungkan demi hukum berlakukah persatuan bulat antara

${ }^{12}$ Hilman Hadikusuma, Hukum Perkawinan Indonesia, menurut Perundangan, Hukum Adat, Hukum Agama, Cetakan 1 (Bandung, Mandar Maju, 1990) h. 123 
harta kekayaan suami dan istri, sekedar mengenai itu dengan perjanjian kawin tidak ditiadakan ketentuan lain.

Peraturan itu sepanjang perkawinan tak boleh ditiadakan atau diubah dengan sesuatu persetujuan antara suami istri. Segala utang dan rugi sepanjang perkawinan harus diperhitungkan atas mujur malang persatuan. Bagi mereka yang tunduk pada Hukum Perdata Barat (BW) mengenai harta yang diperoleh selama perkawinan dalam Pasal 119 BW (KUH Perdata) menyebutkan; Mulai saat perkawinan dilangsungkan, demi hukum berlakulah persatuan antara persatuan bulan antara harta kekayaan suami dan istri, sekadar mengenai itu dengan perjanjian kawin tidak diadakan ketentuan lain. Persatuan itu sepanjang perkawinan tak boleh ditiadakan atau diubah dengan sesuatu persetujuan antara suami dan istri.

Dengan demikian, di dalam pasal ini menunjukan bahwa sepanjang mengenai harta menjadi harta bersama atau harta campuran itu demi undang-undang menjadi hubungan bersama, atau apabila suami istri sebelum melangsungkan perkawinan mengadakan surat perjanjian di hadapan notaries mengenai hartanya, maka suami istri dapat menempuh penyimpangan. Dengan demikian jelas di sini bagi mereka yang tuduk kepada BW mengenai persatuan harta ini adalah bersifat memaksa, yang berarti setelah perkawinan dilangsungkan maka sepanjang yang menyangkut harta bersama tidak dapat diadakan perjanjian lain. Di sini harus dapat kita bedakan bukan berarti bahwa para pihak menjadi hak separo-separo atas harta bersama, apabila kemudian salah satu pihak meninggal dunia, apa yang kita kenal sebagai barang gono gini di dalam Hukum Adat. Ataupun percampuran harta ini akan lebih tepat kalau kita nyatakan, bahwa suami istri masingmasing mempunyai hak atas harta, namun bagi mereka dapat tidak melakukan penguasaan (beschekking) atas bagian mereka masing-masing ${ }^{13}$

\section{E. KESIMPULAN}

Perceraian adalah sesuatu yang sangat dibenci oleh Allah swt. sebagai sebuah akad (misaqan ghaliza) pada tempatnyalah jika perkawinan harus dipertahankan agar tetap harmonis, sakinah, mawaddah dan warahmah. Akan Tetapi seringkali kegagalan manusia dalam mengelola perkawinannya, membuat perceraian menjadi sesuatu yang tidak terhindarkan. Akibatnya perceraian benar-benar terjadi. hukum Islam dalam hal ini undang-undang perkawinan dan KHI telah memberikan beberapa aturan-aturan berkenaan dengan implikasi perceraian itu, seperti masalah pengasuhan anak dan juga harta bersama. Guna aturan-aturan ini adalah, walaupun perceraian tidak diinginkan, jika telah terjadi hendaklah tetap membawa kemaslahatan kedua belah pihak, bukan menimbulkan permusuhan yang berkepanjangan. Harta bersama meliputi: harta yang diperoleh sepanjang perkawinan berlangsung; hutang-hutang yang timbul selama perkawinan berlangsung kecuali yang merupakan harta pribadi masing-masing suami isteri; harta yang diperoleh sebagai hadiah/pemberian atau warisan apabila ditentukan demikian. Suami dan istri yang telah resmi bercerai memiliki hak yang sama terhadap harta bersama, dengan pembagian sama rata.

\footnotetext{
${ }^{13}$ Soedharyo Soimin, Hukum Orang dan Keluarga Persfektif Hukum Perdata Barat/BW Hukum Islam, dan Hukum Adat, Edisi Revisi, (Jakarta, Sinar Grafika) h. 26
} 
Bukhari \& Anwar, Harta Bersama Akibat Perceraian...

\section{DAFTAR PUSTAKA}

Abdul Aziz Dahlan, Ensiklopedi

Abdul Gani Abdullah, Pengantar Kompilasi Hukum Islam Dalam Tata Hukum

Indonesia (Jakarta: Gema Insani Press, 1994),

Abdul Wahab Khallaf, Ilmu Ushul al-Fiqh (Jakarta: Maktabah al-Sa'wah alIslamiyah, 1990)

Al-Nadwi, Ali Ahmad, Qawa'id al-Fiqhiyah, Damsyik: Dar al-Qalam, 1994.

Anwar, Moh Dasar-Dasar Hukum Islam dalam Menetapkan Keputusan di Pengadilan Agama, Semarang: Diponegoro, 1991

Direktur Pembinaan Badan Peradilan Islam, Himpunan Peraturan PerundangUndangan Dalam Lingkungan Peradilan Agama (Jakarta: tp, 2001

Hilman Hadikusuma, Hukum Perkawinan Indonesia, menurut Perundangan, Hukum Adat, Hukum Agama, Cetakan 1 (Bandung, Mandar Maju, 1990)

Lebih lanjut lihat kembali, Ismuha, Pencaharian Bersama Suami istri di
Indonesia, (Jakarta: Bulan Bintang, 1978)

Pagar, "Harta Bersama Suami-Istri (Suatu Tinjauan Terhadap Kompilasu Hukum

Islam) dalam Sinar Darussalam No. 205, AGustus 1993, IAIN. Ar-Raniry, Banda Aceh

M. Quraish Shihab, tafsir Al-Mishbah (Jakarta: Lentera Hati, 2006), Vol. II,

Soedharyo Soimin, Hukum Orang dan Keluarga Persfektif Hukum Perdata Barat/BW Hukum Islam, dan Hukum Adat, Edisi Revisi, (Jakarta, Sinar Grafika)

Khallaf, Abdul Wahab, Ilmu Ushul al-Fiqh, Jakarta: Maktabah al-Sa'wah alIslamiyah, 1990.

Manan, Abdul, Aneka Masalah Hukum Material Dalam Praktek Peradilan Agama, Jakarta: Pustaka Bangsa, 2003.

Manan, Abdul, Aneka Masalah Hukum Perdata Islam di Indonesia, Jakarta Kencana, 2006.

Manan, Abdul dan Fauzan, M, Pokok-Pokok Hukum Perdata Wewenang Peradilan Agama, cet IV, Jakarta: Raja Garfindo Persada, 2001 